\title{
Climate Change Favors Grapevine Production in Temperate Zones
}

\author{
Bruno Koch1, Fritz Oehl2* \\ ${ }^{1}$ Kastanienberg, Hainfeld, Germany \\ ${ }^{2}$ Agroscope, Competence Division for Plants and Plant Products, Ecotoxicology, Wädenswil, Switzerland \\ Email: ^fritz.oehl@gmail.com, fritz.oehl@agroscope.admin.ch
}

How to cite this paper: Koch, B. and Oehl, F. (2018) Climate Change Favors Grapevine Production in Temperate Zones. Agricultural Sciences, 9, 247-263.

https://doi.org/10.4236/as.2018.93019

Received: November 13, 2017

Accepted: March 3, 2018

Published: March 6, 2018

Copyright (c) 2018 by authors and Scientific Research Publishing Inc. This work is licensed under the Creative Commons Attribution International License (CC BY 4.0).

http://creativecommons.org/licenses/by/4.0/

\begin{abstract}
Wine production has a long-standing history in Palatinate (Southwestern Germany), dating back to Roman times. Especially "Riesling", but also several "Pinot" varieties gained major significance. Red wine varieties gained prominence over the last 20 years only, which may be a consequence of climate change. Our objective was to review temperature and rainfall data over the last 40 years, measured "on-winery" in Hainfeld and correlate these data with grapevine growth parameters: the development of bud break, flowering, veraison and harvest dates, yields and grape sugar concentrations of "Pinot Gris", "Pinot Noir", "Riesling", "Silvaner" and "Müller-Thurgau". Since the 1970s, bud break, flowering and veraison are $11-15,18$ - 22 and 16 - 22 days earlier; harvest dates are 25 - 40 days earlier. Sugar concentrations increased significantly, but yields decreased. Annual rainfall has not significantly risen, while the mean annual minimum and maximum air-temperatures rose by $\sim 0.9^{\circ} \mathrm{C}$, and by $\sim 3.4^{\circ} \mathrm{C}$, respectively, resulting in an average increase of the mean annual temperature of $\sim 2.1^{\circ} \mathrm{C}$. Remarkably, both mean monthly minimum and maximum temperatures rose especially in springtime, which should have been the driver for earlier bud break and flowering. A change in the climatic conditions, therefore, appears to be one of the key reasons for more favorable grapevine production in Palatinate, especially for "Pinot Noir", which showed the highest increase in sugar concentrations. The Huglin-index, a measure for the suitability of growing specific grapevine varieties in given environments, increased from 1685 to 2063. According to this index, the climate change may be favorable already for growing grape varieties so far rarely grown in temperate zones, such as "Cabernet Sauvignon", "Syrah" and "Tempranillo" that are more suited to warmer, Mediterranean climates.
\end{abstract}

\section{Keywords}

Central Europe, Climatic, Diversity, Viticulture, Vitis vinifera 


\section{Introduction}

Climate change will undoubtedly affect global crop production in terms of productivity, as well as the relative distribution, and suitability, of particular crops and varieties of these crops, including grapevine and wine production. The changes in temperatures and rainfall are key drivers in this respect, which directly impact on crop development and productivity, but also in respect to changes in pest and pathogen spectra [1] [2] [3] [4] [5]. Wine production in the regions of southwestern Germany, northeastern France and northern Switzerland, along the Rhine River and its tributaries, such as the Aare, Thur-Ill, Neckar, Nahe, Main, Saar-Mosel and Ahr, has been a long-standing tradition, dating back to the Roman times. Traditional white grapevine varieties, such as "Riesling" and "Silvaner" or several "Pinot" varieties, are characteristic of these wine growing areas, and the wines produced here have achieved worldwide recognition for their quality and distinction [6]. Some more recent introductions, as "Müller-Thurgau", also referred to as "Rivaner" or "Riesling $\times$ Silvaner", which was crossed in Geisenheim (Germany) between "Riesling" \& "Chasselas" and propagated first in Wädenswil (Switzerland) [7], or "Dornfelder", developed in Weinsberg [8] [9], have also achieved major recognition from the region. In Southern Palatinate, represented by the German Wine Road, the traditional and more recently introduced varieties have provided significant success in the global arena for winegrowers [6].

General observations indicate that in Palatinate, over the past few decades, harvest dates appear to have gradually shifted, becoming earlier, while the proportionate area of production for red wine has increased, including an expanded range of red wine varieties. This includes the new variety "Dornfelder", but also traditional varieties more associated with warmer wine growing areas, such as "Merlot" and, more rarely, also "Cabernet Sauvignon" from Bordeaux (Southwest of France) or "Syrah" from Côte du Rhone, Languedoc, Toscany and Sicily (Italy). These observations indicate that, among other factors, such as new cultivation and management techniques, and/or improved wine-growing skills, changes in climatic conditions may be contributing to the shift from more traditional to more "exotic" grape varieties [10].

In the current study, we assessed 40-years' worth of comprehensive field data and measurements on climate, phenology and crop growth parameters recorded by the principal author in Hainfeld, Southern Palatinate, Germany. The main objective was to correlate the climatic data with the phenological and harvest data for five major grapevine varieties of the region, assess the implication of the results to current regional crop growing practices and the influence of climate change to future challenges on a local, regional and global scale.

\section{Materials and Methods}

\subsection{Vineyard Site Details and Grapevine Varieties}

The winery Kastanienberg in Hainfeld (Südliche Weinstrasse, Palatinate, Ger- 
many; $49^{\circ} 15^{\prime} \mathrm{N} ; 8^{\circ} 06^{\prime} \mathrm{O}$ ) is located directly on the "German Wine Road", within the wine growing region Palatinate. This route, as with the "Route du Vins d'Alsace", which is approximately $100 \mathrm{~km}$ further South, extends for over $80 \mathrm{~km}$ along the Rhine valley on gentle hills, between Triassic "Bundsandstein" mountains and the river, comprising approximately $229 \mathrm{~km}^{2}$ of winelands.

For this study, four varieties of white wine ("Riesling", "Silvaner", "Müller-Thurgau", "Pinot Gris") and the red wine variety "Pinot Noir" were selected from the winery to investigate phenological and first annual harvest dates, grapevine juice concentrations (measured on-winery as juice density in ${ }^{\circ}$ Oechsle) and the annual juice quantities in hL per hectare since 1975. The varieties differ, among other characters like sugar and acid formation or suitability in specific soil types, also in dates of ripening: "Müller-Thurgau" has been counted as a early ripening variety in Germany, while traditionally "Silvaner" were attributed as "middle late", and "Riesling", "Pinot Gris" and "Pinot Noir" as "late ripening". In this way, we covered the whole range of traditionally grown, important grapevine varieties with respect to early or late ripening and harvest dates.

For each grapevine variety a single vineyard was selected, planted in the 1970 's, or vineyards where old rootstocks had been replaced by rootstocks of the same variety and, if possible the same clone of the same variety. The "Pinot Gris" was planted in 1975 and replanted in 2014. The "Riesling" was planted in 1968 (old "Bürklin" clone) and replanted with in 2005. The "Silvaner" (clone 26/93) was planted in 1968, and replanted in 2006. The data of "Müller-Thurgau" are from four vineyards in total, planted in the 1970-1980's, but in different years. The "Pinot Noir" vineyard was planted in 1989, which provided a first harvest in 1991.

In Hainfeld, the soils are predominantly silty to loamy Luvisols and sandy to clayey Cambisols, generally with a moderate to high soil fertility and nutrient availability. Geologically located in the depression zone of the Rhine valley between Basel, Strasbourg and Mainz, the soils have developed on a wide range of bedrocks from the Triassic period and are partly covered by sandy-alluvial or silty-Loess material from the Quaternary. Thus, they cover a diverse range of sandy to clay soils, of quite different $\mathrm{pH}$ and water holding capacity, representing very well a manifold Terroir [11] of Palatinate on a very local scale.

\subsection{Phenological and Harvest Data}

The dates for bud break, flowering (onset) and veraison (= onset of ripening) were recorded annually since 1974 for the five cultivated varieties grown in Hainfeld. Since 1974, also the harvest dates, harvest quantities (hL grapevine juice per ha) and grapevine sugar concentrations (measured as juice densities in 'Oechsle) were documented annually since 1975, starting from the first harvest for each grown variety. 


\subsection{Climatic Data Obtained at Winery}

Daily rainfall was measured by a standard rain gauge all year long since 1970 . Since 1975, daily minimum and maximum temperatures were measured daily, throughout the year. Mean annual temperature was calculated by the average of the mean annual maximum and mean annual minimum temperature. Daily minimum and maximum temperatures between April and September are the base to calculate the "Huglin index", a specific climatic index for wine growing areas. It was calculated according to Huglin [12] using the following equation:

$$
\begin{aligned}
H I & =K * \sum\left(T_{\text {average }}+T_{\max }-20\right) / 2 \\
& =K * \sum\left(\left(T_{\min }+T_{\max }\right) / 2+T_{\max }-20\right) / 2
\end{aligned}
$$

where $K$ is in this formula a latitude dependent coefficient (here $K=1.05825$ for latitude $49^{\circ} 15^{\prime} \mathrm{N}$ ), $T_{\min }$ is the daily minimum temperature, $T_{\max }$ the daily maximum temperature, and $T_{\text {average }}$ the daily average temperature, calculated for daily between $1^{\text {st }}$ April and $30^{\text {th }}$ September of each year. For this study, we calculated the Huglin index annually between 1975 and 2015 for the village Hainfeld, based on our data from the winery.

\subsection{Statistical Analyses}

Linear regressions were applied to data to assess for date changes in bud break, flowering and harvest, annual sugar concentrations and harvest quantities per grapevine variety. We calculated the mean monthly and annual precipitation $\left(\mathrm{mm} \cdot\right.$ rainfall $\left.\cdot \mathrm{m}^{-2}\right)$, and the mean monthly and annual minimum and maximum temperatures, and, as a consequence of the two later data sets, also the daily, monthly and annual average temperatures and the Huglin index (see above) for the village Hainfeld (Pfalz). Beginning 1975, we summarized data into 10-year blocs (1975-1984, 1985-1994, 1995-2004, and 2005-2014) and conducted ANOVA followed by Fisher's Least Significant differences (LSD), and-without the blocs-linear regressions, to determine monthly and annual rainfall and temperature changes over time.

\section{Results}

\subsection{Sugar Concentrations and Harvest Quantities in the Grapevine Varieties Since 1975}

Juice densities were slightly elevated in the varieties "Riesling", "Silvaner" and "Müller-Thurgau" since the 1970's, but with relatively low $\mathrm{r}^{2}$-values of $0.14-0.18$ $(p=0.001-0.01$; Figure 1(a)). Expressed as averages between 1975-1984 and 2005-2014, or calculated from the linear regressions in Figure 1(a) between 1975-2015, we obtained an average increase in juice density of $\sim 9-17^{\circ}$ Oechsle for these varieties (Table 1). Sugar concentrations did not increase in "Pinot Gris" ( $r^{2}=0.01 ; p=0.63$ ), which had the highest sugar concentrations of the white wine varieties since 1975 without exception in any year. Remarkably, for 

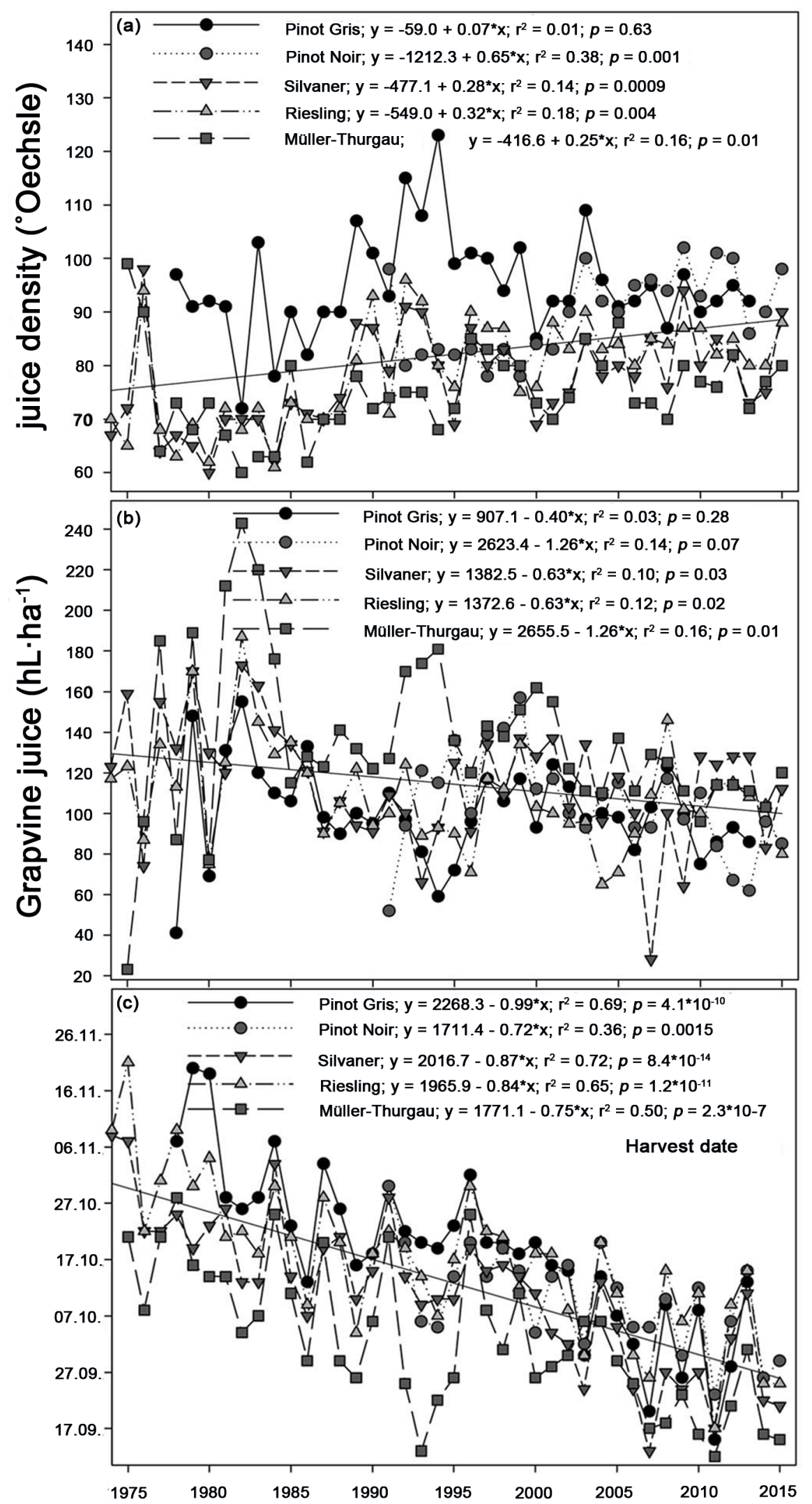

Figure 1. Juice density (in ${ }^{\circ}$ Oechsle, (a), juice quantity (in $\mathrm{hL} \cdot \mathrm{ha}^{-1},(\mathrm{~b})$, and harvest dates, (c), for five grapevine varieties from 1975-2015. 
Table 1. Mean juice density (in ${ }^{\circ}$ Oechsle) and mean juice quantity (in $\mathrm{hL} \cdot \mathrm{ha}^{-1}$ ) in five grapevine varieties in Hainfeld (SW Germany) during ten year periods from 1975-2014.

\begin{tabular}{|c|c|c|c|c|c|c|}
\hline $\begin{array}{c}\text { Juice density } \\
\text { ('Oechsle) }\end{array}$ & 1975-1984 & 1985-1994 & 1995-2004 & 2005-2014 & $\begin{array}{l}\text { Increase by } \\
\text { difference }\end{array}$ & $\begin{array}{c}\text { Increase by } \\
\text { linear } \\
\text { regression }\end{array}$ \\
\hline Pinot Gris & 89.1 & 99.9 & 97.0 & 92.3 & 3.2 & 2.8 \\
\hline $\begin{array}{l}\text { Pinot Noir } \\
\text { (since 1991) }\end{array}$ & - & 85.8 & 85.3 & 94.7 & 8.9 & 15.6 \\
\hline Silvaner & 69.8 & 79.8 & 83.5 & 83.4 & 13.6 & 11.2 \\
\hline Riesling & 66.4 & 72.4 & 83.5 & 83.4 & 17.0 & 12.8 \\
\hline Müller-Thurgau & 66.4 & 72.4 & 78.9 & 76.8 & 12.4 & 10.0 \\
\hline $\begin{array}{l}\text { Juice quantity } \\
\left(\mathrm{hL} \cdot \mathrm{ha}^{-1}\right)\end{array}$ & 1975-1984 & 1985-1994 & 1995-2004 & 2005-2014 & $\begin{array}{l}\text { Decrease by } \\
\text { difference }\end{array}$ & $\begin{array}{c}\text { Decrease by } \\
\text { linear } \\
\text { regression }\end{array}$ \\
\hline Pinot Gris & 110.6 & 96.9 & 103.5 & 94.0 & -15.4 & -16.0 \\
\hline $\begin{array}{l}\text { Pinot Noir } \\
\text { (since 1991) }\end{array}$ & - & 110.0 & 120.5 & 93.4 & $-17.1(-6.6)$ & -30.2 \\
\hline Silvaner & 141.7 & 100.5 & 119.4 & 100.1 & -41.6 & -5.2 \\
\hline Riesling & 128.8 & 107.2 & 98.3 & 105.9 & -22.9 & -25.2 \\
\hline Müller-Thurgau & 150.8 & 141.3 & 134.8 & 115.1 & -35.7 & -50.4 \\
\hline
\end{tabular}

red wine "Pinot Noir" sugar concentrations increased since 1991, with highest $\mathrm{r}^{2}$ obtained for all five varieties $\left(\mathrm{r}^{2}=0.38 ; p=0.001\right.$; Figure $\left.1(\mathrm{a})\right)$.

Grapevine juice yield produced per year decreased in "Riesling", "Silvaner" and "Müller-Thurgau" since the 1970's (although with low $\mathrm{r}^{2}$-values of 0.12 $0.16 ; p=0.01-0.03)$, which was not significant for the "Pinot" varieties $\left(\mathrm{r}^{2}=\right.$ $0.03-0.11 ; p=0.07-0.28$; Figure 1(b)). Expressed as averages between 1975-1984 and 2005-2014, or calculated from the linear regressions between 1975-2015 (Figure 1(b)), juice yields decreased by approx. $15 \mathrm{hl} \cdot \mathrm{ha}^{-1}$ for "Pinot Gris", 17 - $30 \mathrm{hl} \cdot \mathrm{ha}^{-1}$ for "Pinot Noir", 22 - $25 \mathrm{hl}^{-h^{-1}}{ }^{-1}$ for "Riesling", 25 - 41 hl.ha ${ }^{-1}$ for "Silvaner", and $35-50 \mathrm{hl} \cdot \mathrm{ha}^{-1}$ for "Müller-Thurgau" (Table 1).

\subsection{Grapevine Harvest Dates Since 1975}

The grapevine harvest dates clearly changed for all five varieties investigated (Figure $1(\mathrm{c})$ ). The $\mathrm{r}^{2}$-values were high for all white wine varieties $(0.50-0.72)$, and lower for "Pinot Noir" (0.36), which had not been grown on the winery prior to 1988. Initial harvesting dates switched from early/mid October to mid September for "Müller-Thurgau", and from end October/early November to early October/end September for "Riesling", "Silvaner" and "Pinot Gris" (Figure $1(\mathrm{c})$ ). This corresponds to an approximate 26 days earlier harvesting date for "Müller-Thurgau", 27 days for "Riesling", 29 days for "Silvaner", and 37 days for "Pinot Gris" between the decades 1975-1984 to 2005-2015 (Table 2). For "Pinot Noir", no data existed for 1975-1990, but a similar trend was recognized as for "Pinot Gris" between 1991 and 2015 with harvests conducted approximately 10 days earlier over the period of study (Figure 1(c)). When data on the date of harvest 
Table 2. Mean annual first harvest dates and earlyness of harvest in five grapevine varieties in Hainfeld (SW Germany) during ten year periods from 1975-2014.

\begin{tabular}{ccccccc}
\hline $\begin{array}{c}\text { Harvest date } \\
\text { (days) }\end{array}$ & $1975-1984$ & $1985-1994$ & $1995-2004$ & $2005-2014$ & $\begin{array}{c}\text { Earlyness of } \\
\text { harvest } \\
\text { (by difference, } \\
\text { in days) }\end{array}$ & $\begin{array}{c}\text { Earlyness of } \\
\text { harvest } \\
\text { (by regression) }\end{array}$ \\
\hline $\begin{array}{c}\text { Pinot Gris } \\
\text { Pinot Noir } \\
\text { (since 1991 }\end{array}$ & 6.11. & 22.10. & 18.10. & 01.10. & 37 & $40(55)$ \\
$\quad$ Silvaner & 24.10. & 15.10. & 10.10. & 26.09. & 29 & 28 \\
Riesling & 30.10. & 16.10. & 17.10. & 04.10. & 27 & 25 \\
Müller-Thurgau & 16.10. & 02.10. & 05.10. & 21.09. & 26 & 34 \\
\hline
\end{tabular}

*The "Pinot Noir" vineyard was planted in 1989, which provided a first harvest in 1991.

between 1975 and 2015 were regressed, (Figure 1(c)), similar results were obtained as from the ANOVA analyses between 1975-1984 and 2005-2014: 25 days for "Silvaner", 30 days for "Müller-Thurgau" and 34 days for "Riesling", and also for "Pinot Noir" a similar number of days was extrapolated (28 days; Table 2). For "Pinot Gris" harvest dates became earlier by 55 days, which is affected by the very late harvest dates in 1979 and 1980 (late November), while in 2011 harvest was 67 days earlier, compared to 1979/1980. When calculating the regression between 1981 and 2013 only, harvest dates were 40 days earlier $(y=2267.3-$ $0.99^{\star} \mathrm{x} ; \mathrm{r}^{2}=0.61, \mathrm{p}=7.8^{\star} 10^{-8}$ ) for Pinot Gris (Table 2).

\subsection{Bud Break, Flowering and Ripening Since 1975}

Bud break, flowering and ripening ("veraison") dates clearly changed for all five varieties over the period of study (Figure 2). Following linear regression, bud break across varieties became $11-15$ days earlier since 1975, flowering $18-22$ days and onset of ripening $16-22$ days. The $\mathrm{r}^{2}$-values were $0.27-0.43(p<$ $\left.8.6^{\star} 10^{-4}\right)$, except for "Pinot Noir" for bud break, which was planted later $\left(\mathrm{r}^{2}=\right.$ $0.17 ; p=0.028$ ). The bud break dates generally switched from end April/early May to end/middle April, flowering dates from late June/early July to early/middle June, and veraison from early/middle September to middle/end August (Figure 2).

\subsection{Annual and Monthly Rainfall}

Linear regression did not reveal any significant change in annual precipitation between 1970 and 2015 (Figure 3), although there was relatively lower precipitation in the first decade $(573 \mathrm{~mm})$. The mean annual precipitations recorded were 643, 700, 722 and $686 \mathrm{~mm}$ within periods of 1975-1984, 1985-1994, 1995-2004 and 2005-2014, respectively (Table 3). Linear regressions did not reveal any change in monthly rainfall over the 45 years for any of the twelve months (data not shown). However, remarkably, ANOVA showed clear differences in rainfall between the months and a bimodal precipitation curve throughout the year, with 


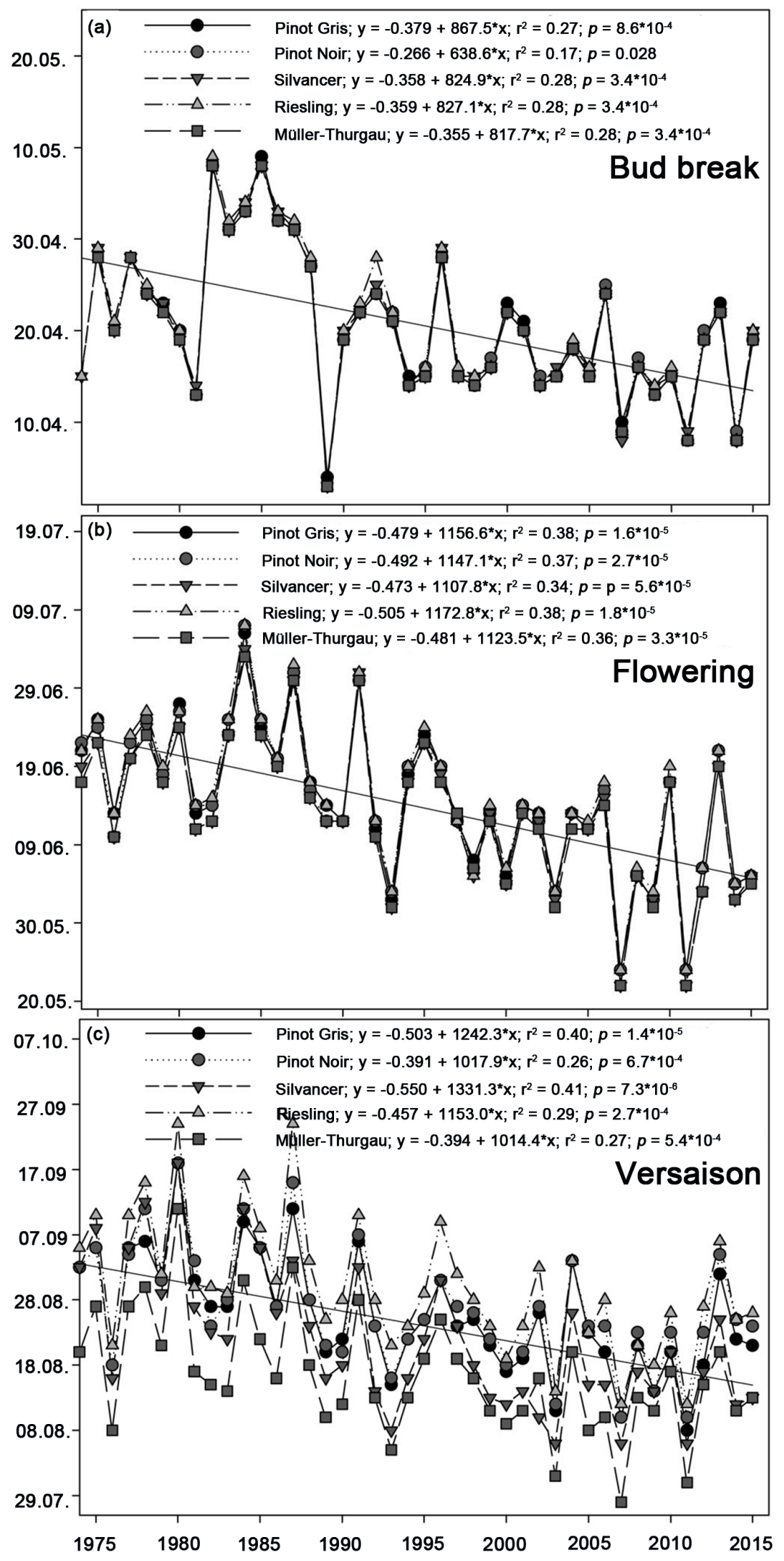

Figure 2. Annual dates for bud break, flowering and veraison on-winery for five grapevine varieties in Hainfeld (SW Germany) from 1975-2015. 


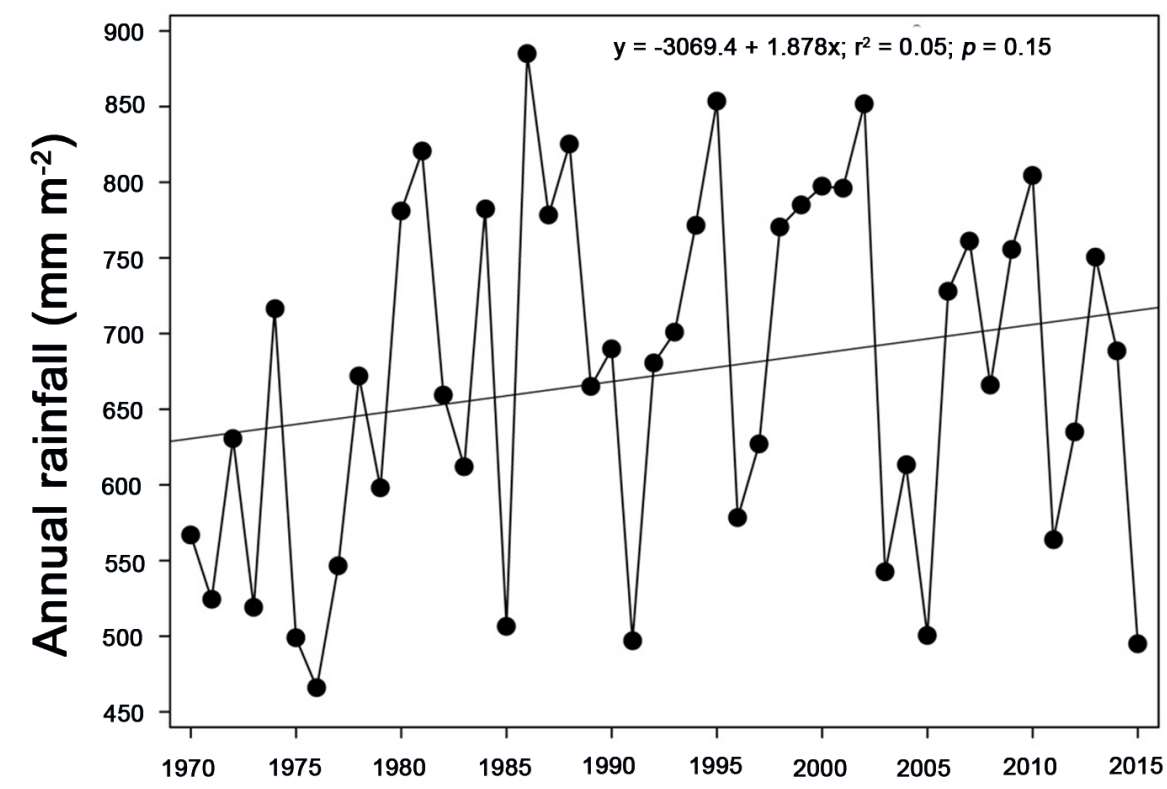

Figure 3. Annual precipitation in Hainfeld (SW Germany) from 1970-2015.

Table 3. Mean annual rainfall, mean annual temperatures and Huglin index for Hainfeld (SW Germany) during ten year periods from 1970-2014.

\begin{tabular}{lccccccc}
\hline & $1970-1974$ & $1975-1984$ & $1985-1994$ & $1995-2004$ & $2005-2014$ & $p^{*}$ & LSD \\
\hline $\begin{array}{l}\text { Mean annual } \\
\text { precipitation }\end{array}$ & $591^{*}$ & $643 \mathrm{a}$ & $700 \mathrm{a}$ & $722 \mathrm{a}$ & $686 \mathrm{a}$ & 0.502 & n.d. \\
$\begin{array}{l}\text { Mean annual minimum } \\
\text { temperature }\end{array}$ & n.d. & $6.94 \mathrm{a}$ & $6.61 \mathrm{a}$ & $7.22 \mathrm{a}$ & $7.62 \mathrm{a}$ & 0.007 & 0.563 \\
$\begin{array}{l}\text { Mean annual maximum } \\
\text { temperature }\end{array}$ & n.d. & $14.1 \mathrm{c}$ & $14.2 \mathrm{c}$ & $15.5 \mathrm{~b}$ & $16.8 \mathrm{a}$ & $3.6^{*} 10^{-6}$ & 0.955 \\
$\begin{array}{l}\text { Mean annual } \\
\text { temperature }\end{array}$ & n.d. & $10.5 \mathrm{c}$ & $10.4 \mathrm{c}$ & $11.3 \mathrm{~b}$ & $12.2 \mathrm{a}$ & $3.8^{\star} 10^{-5}$ & 0.727 \\
$\begin{array}{l}\text { Huglin index } \\
\text { n.d. }\end{array}$ & $1688 \mathrm{c}$ & $1685 \mathrm{c}$ & $1858 \mathrm{~b}$ & $2063 \mathrm{a}$ & $8.6^{*} 10^{-5}$ & 165.3 \\
\hline
\end{tabular}

Average of ten years. ${ }^{*}$ Average of 5 years. LSD denotes Least Significant Difference after one-way ANOVA. Data in the same line with same letter are not significantly different from each other.

increased rainfall during late spring to early summer (May to July) and especially at the end of autumn to early winter (October to January, Figure 4). Since 1970, rainfall was lowest in April, August and September (41, 47 and $50 \mathrm{~mm}$ ), and highest in November and December (65 and $74 \mathrm{~mm}$, respectively).

\subsection{Mean Annual and Monthly Temperatures and Huglin Index}

Mean annual temperatures generally increased between 1975-2015 (Figure 5). Mean maximum temperatures increased from $14.1^{\circ} \mathrm{C}$ in $1975-1984$ and 1985-1994 to $16.8^{\circ} \mathrm{C}$ in $2005-2014$, and the mean annual minimum temperatures increased from $6.9^{\circ} \mathrm{C}$ to $7.6^{\circ} \mathrm{C}$ in the same period (Table 3). This resulted in an increase in the average annual temperatures, from $10.5^{\circ} \mathrm{C}$ to $12.2^{\circ} \mathrm{C}$ between 1975-1994 and 2005-2014 (Table 3). Linear regressions of the mean annual 


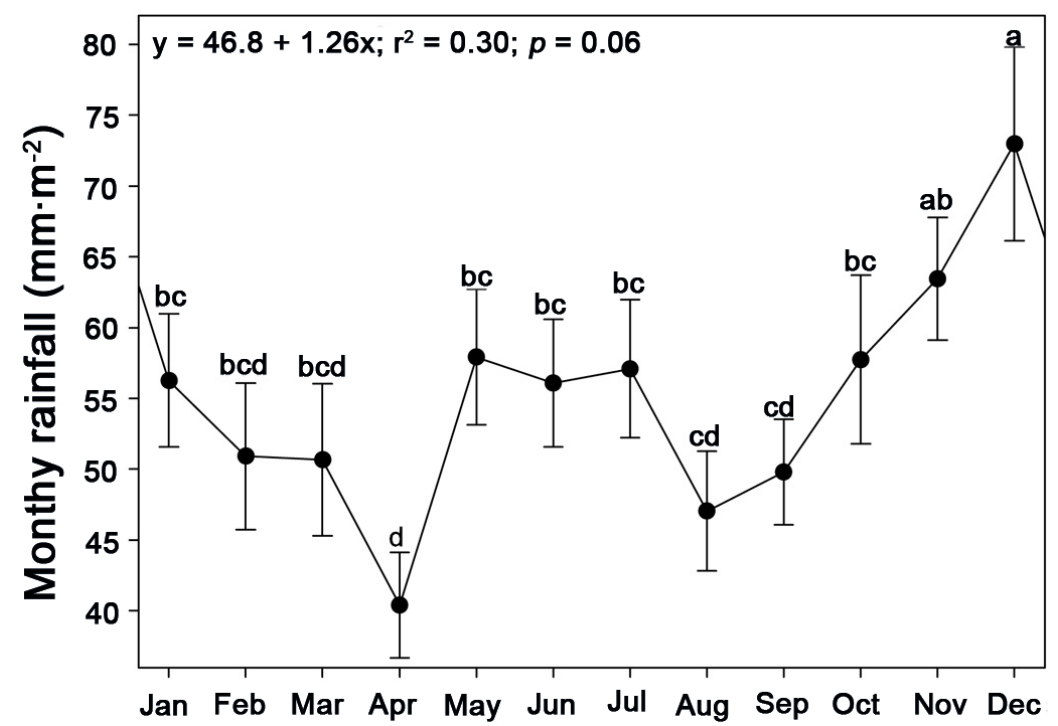

Figure 4. Mean monthly precipitation in Hainfeld (SW Germany) from 1970-2015. Average and standard deviation of fouty years. Nonsignificant differences between sites are indicated by identical letters above the bars and were determined by using Fisher's LSD test at the 5\% level after a one-way ANOVA.

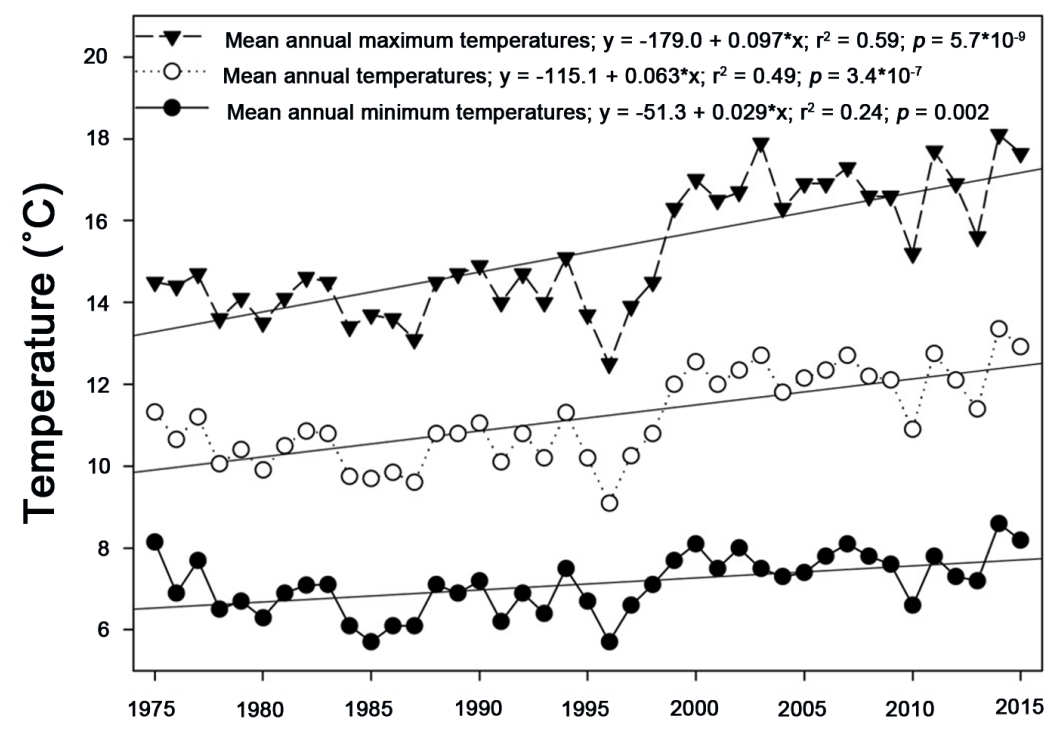

Figure 5. Mean annual temperatures in Hainfeld (SW Germany) from 1975-2015.

maximum, minimum and average temperatures confirm the temperature increases for Hainfeld since 1975 (Figure 5), with high $\mathrm{r}^{2}$-values (0.49 and 0.59, respectively) and low $p$-values $\left(p<1.1^{\star} 10^{-5}\right)$ for the mean annual maximum and average temperatures ( 0.49 and 0.59 , respectively), while the $p$-value for the mean annual minimum temperatures was rather close to the significance level ( $p$ $\left.=0.002 ; r^{2}=0.24\right)$. According to the slopes of the linear regressions, the mean annual minimum, average and maximum temperatures rose by 1.1, 2.5, and $3.8^{\circ} \mathrm{C}$ between 1975 and 2015 . 
Linear regressions for mean monthly temperatures were remarkable, showing significant increases of the mean monthly maximum temperatures for all twelve months ( $\mathrm{r}^{2}$-values 0.11 - 0.49; Table 4). Linear regressions indicated increases in mean monthly minimum temperatures since 1975 for April, May and November $\left(\mathrm{r}^{2}\right.$-values $0.29,0.12$ and 0.16 , respectively), while for the other months only low $r^{2}$-values $(0.00-0.09)$ and high $p$-values of up to 0.70 were generally obtained (Table 4). Consequently, the Huglin index was also seen to increase between 1975 and 2015 (Figure 6). On average, the index rose from 1685 to 1687 in the periods 1975-1984 and 1985-1994 to 2063 in 2005-2014 (Table 3).

\section{Discussion}

Our study demonstrates a clear change in the dates of bud break, flowering, veraison and harvest for five grape varieties over a period of approximately 40 years in Hainfeld, all of which are now significantly earlier than 40 years ago. The earlier bud break certainly had an effect on the increasing earliness of flowering, ripening and harvest over the last two decades. For the five varieties studied, bud break, flowering and veraison occurred $11-15,18$ - 22 and $16-22$ days earlier within the year, and harvest about four to six weeks earlier than 40 years ago. Such findings cannot be explained by changes in cultivation and management techniques alone. In particular, bud break is largely independent of cultivation and management techniques, but should be related to climate change. Trends for earlier grapevine bud break and flowering have been increasingly reported from various regions in Central Europe [13] [14] [15] [16] [17], which were, in some cases, related to earlier veraison or harvest dates [13] [18].

Table 4. Mean monthly temperatures for Hainfeld (SW Germany) from 1975-2015.

\begin{tabular}{|c|c|c|c|c|c|c|}
\hline & \multicolumn{3}{|c|}{ Minimum temperatures } & \multicolumn{3}{|c|}{ Maximum temperatures } \\
\hline & Linear regression & $r^{2}$ & $p$-value & Linear regression & $r^{2}$ & $p$-value \\
\hline January & $y=-72.5+0.04^{*} x$ & 0.04 & 0.226 & $y=-172.1+0.09^{*} x$ & 0.15 & 0.013 \\
\hline February & $y=-57.5+0.03^{\star} x$ & 0.02 & 0.350 & $y=-219.9+0.11^{\star} x$ & 0.19 & 0.003 \\
\hline March & $y=-13.4+0.01^{\star} x$ & 0.00 & 0.699 & $y=-237.1+0.12^{\star} x$ & 0.30 & $2.1^{*} 10^{-4}$ \\
\hline April & $y=-111.7+0.06^{*} x$ & 0.29 & $2.9^{*} 10^{-4}$ & $y=-310.0+0.16^{*} x$ & 0.49 & $2.9^{*} 10^{-7}$ \\
\hline May & $y=-63.9+0.04^{\star} x$ & 0.12 & 0.029 & $y=-125.9+0.07^{\star} x$ & 0.17 & 0.008 \\
\hline June & $y=-20.0+0.02^{\star} x$ & 0.03 & 0.291 & $y=-75.9+0.05^{\star} x$ & 0.12 & 0.027 \\
\hline July & $y=-57.9+0.04^{\star} x$ & 0.09 & 0.052 & $y=-83.6+0.05^{\star} x$ & 0.11 & 0.032 \\
\hline August & $y=-17.4+0.02^{\star} x$ & 0.03 & 0.307 & $y=-146.0+0.09^{\star} x$ & 0.29 & $2.6^{*} 10^{-4}$ \\
\hline September & $y=-4.6+0.01^{\star} x$ & 0.01 & 0.656 & $y=-176.6+0.10^{\star} x$ & 0.22 & 0.002 \\
\hline Oktober & $y=-18.2+0.01^{\star} x$ & 0.01 & 0.484 & $y=-224.9+0.12^{\star} x$ & 0.38 & $1.6^{*} 10^{-5}$ \\
\hline November & $y=-109.2+0.06^{*} x$ & 0.16 & 0.009 & $y=-228.1+0.12^{\star} x$ & 0.37 & $2.7^{*} 10^{-5}$ \\
\hline December & $y=-64.1+0.03^{*} x$ & 0.05 & 0.148 & $y=-137.0+0.08^{*} x$ & 0.18 & 0.006 \\
\hline
\end{tabular}

Bold $p$-value $<0.05$ show significant slope on the linear regression performed, and thus, significant changes in monthly temperatures from 1975 to 2014 for the respective month. 


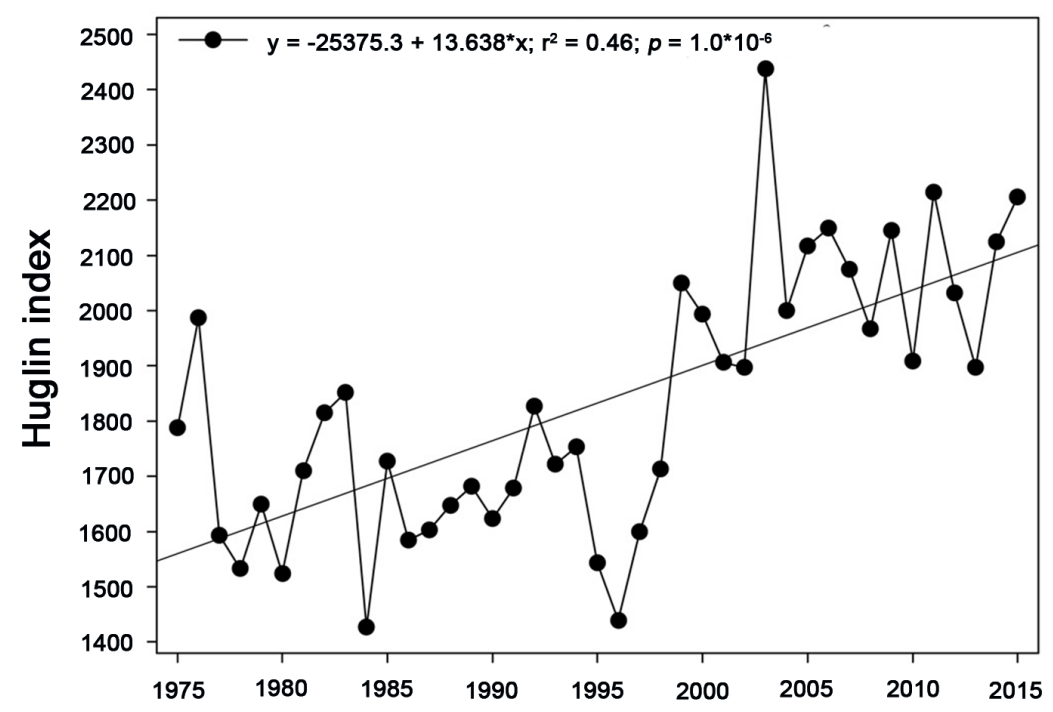

Figure 6. Huglin index in Hainfeld (SW Germany) increased from 1975-2015.

Analysis of the data in our study shows that the mean annual temperatures in Hainfeld have increased by $1.7^{\circ} \mathrm{C}-2.5^{\circ} \mathrm{C}$ over the last 40 years, a figure substantially higher than the global land-surface air temperature rise of approximately $0.18^{\circ} \mathrm{C}$ per decade since 1950 [19]. Both mean monthly minimum and maximum temperatures show that the temperature increases especially during spring (April and May), which relate to bud break and the beginning of flowering. Furthermore, the mean annual maximum temperatures have increased throughout the year, which would tend to relate to a faster plant development and to higher rates of photosynthesis, and thus sugar production of the grapes during the vegetation period, as evidenced in the study. Also, the Huglin index demonstrates an increased suitability for production of grapevine varieties that are more suited to warmer Mediterranean climates, especially for red wine production. The increasing mean annual temperatures since 1975 and the overall climate change in Hainfeld strongly correlate with the significantly earlier bud break, onset of flowering and veraison. Our findings similarly correspond with trends for "Riesling" shown by Duchêne \& Schneider [13] obtained for the period of 1972-2002 in Colmar (Southern Alsace, France).

Four of the five grapevine varieties appear to have responded to this increase in temperature by producing higher juice sugar concentration, and by consequence, a higher wine quality, while for the fifth variety, "Pinot Gris", harvest has become five to six weeks earlier than 40 years ago. However, in some of the warmer and dryer years a decrease of natural grapevine acids, especially in white wines, has led to complaints [15] [20], resulting in governmental permission to artificially correct for such acid deficiencies in Germany for specific years. In response to this change, efforts have been initiated to identify in particular new "Riesling" and other clones of traditional white wines that will be more suited to the warmer climate, than the traditionally used clones [21] [22]. In the past one of the challenges in the North of the Alps was to find clones of traditional white 
wine varieties or new varieties that would ripen earlier [7]. Nowadays, it has become more favorable to look for or recover those clones/varieties that ripen later [23]. According to Schultz \& Jones [18], the projected temperature rise will alter wine composition and wine styles, and combined with the predicted changes in rainfall volume and timing, will further challenge viticulture in the future. Similarly, the same and other authors [18] [24] expect that such changes in the climate will result in a shift in grape growing boundaries.

For our situation in Hainfeld, we can summarize that over the last four decades temperature has already changed significantly, while rainfall has remained relatively consistent. Further temperature increases of $1^{\circ} \mathrm{C}-2^{\circ} \mathrm{C}$ within the next 20 - 50 years, as can be expected, will certainly affect the traditional white wine production of southwestern Germany, and lead to a further increase in the red wine production, through more favorable conditions. The shift from white to red wine production in Palatinate will likely be based on temperature increases in the region. The Huglin indices measured during the last decade also indicates that red wine varieties previously considered "exotic", such as "Syrah" and "Tempranillo", can now be grown successfully in Palatinate and neighbored regions [25] [26]. It is likely that with further changes in climate, varieties such as "Merlot" and "Cabernet Sauvignon", will gain further prominence in the region and compete successfully with traditional varieties, such as "Portugieser", "Pinot Noir" and "Dornfelder" that are more adapted to the so far "cold grapevine climates" of approximately $10^{\circ} \mathrm{C}$ mean annual temperatures. Such low mean annual temperatures have become increasingly rare in grapevine growing southwestern Germany within the last twenty years.

An increasingly warmer climate will certainly not only affect the range of grapevine varieties and the wine quality in colder climates, such as in Germany and neighboring countries, but also the occurrence of grapevine pests and pathogens originating from warmer climates [4]. Some are already being detected increasingly in Palatinate or can be expected soon, such as the American grapevine leafhopper, or flavescence dorée disease, which has already been detected in western Switzerland [27] [28]. Other, more traditional pests and pathogens may reduce in importance, as temperatures increase e.g. downy mildew [29] [30]. However, there is no escaping the fact that since the introduction of viticulture into the Rhine Valley Region by the Romans, wine production has been a continuous challenge, with repeated climate changes since that time [2]. Nevertheless, it seems that current changes are at least partly "man-made" and that rates of change and consequent challenges may have accelerated and/or multiplied.

Simulation of the impact of climate change on the distribution of the most important European wine regions has demonstrated the potential for a dramatic change in the landscape for wine production in Europe and worldwide due to changes in climate, especially in warmer grapevine growing areas [3] [31]. Other studies, however, argued that changes in climate will not dramatically affect the suitability of viticulture in the main wine-growing regions before 2050 [32] [33], or for other important fruits, such as olives [34]. Impacts on photosynthesis, 
fruit and wine quality, do not necessarily depend only on climatic conditions [35], but may regionally and locally be affected for instance by soil characteristics [36], or water availability. One major constraint for the future of grapevine and wine production certainly concerns water status [37]. With increasing temperatures, the need to irrigate vineyards may become more crucial, especially where water is a limiting factor. There are certainly several extreme examples within the world, where wine production systems are almost 100\% dependent on irrigation or on efficient nocturnal condensation, such as in the semi-arid, sub-tropics and tropics. Moreover, extreme conditions in hot wine-making regions is likely to have an overall negative impact on wine quality [24] [38], e.g. by altering the composition of organic compounds in the juices and wines, leading to unfavourable ratios of sugar and acid concentrations, and the amount and composition of phenolic compounds [39].

Comparing our data with those of Duchêne \& Schneider [12], we can conclude that in the Rhine valley between Basel, Freiburg, Colmar, Strasbourg, Landau, Neustadt and Geisenheim, at least local and regional warming has already reached or even passed $2.0^{\circ} \mathrm{C}$ within the last few decades. It can be further concluded that global warming could accelerate over the next 20 - 50 years. We therefore assume that grapevine and wine production can dramatically change further within this century, especially in warm and arid wine growing regions [3]. However, not only grapevine, or olive production face such problems, but across the agricultural spectrum climate change will variously affect production and quality, especially in semi-arid to arid, warmer climates, where thousands of hectares of productive agricultural land have already been lost due to severe drought, desertification, salinization, heavy rain events, flooding or erosion.

\section{Conclusion}

Over the previous four decades, mean annual and mean monthly rainfall have not significantly changed in Palatinate; mean annual and mean monthly temperatures have significantly increased however, especially during the vegetation period of grapevine, significantly affecting grapevine growth, phenology and juice quality. Climate has changed and most likely will further change wine production in Palatinate, and in other traditionally cooler European grapevine growing areas, such as Alsace or Franconia, towards more favorable conditions for successful red wine production, but at the expense of the traditional highly appreciated white wines, especially "Riesling" and "Silvaner". The changes in climate will furthermore affect the pest and pathogen spectrum. In conclusion, researchers need to be cautious in many aspects to protect and develop further the grapevine production in these traditional wine growing areas north of the Alps.

\section{Acknowledgements}

We acknowledge Werner \& Andrea Koch from the Organic winery Kastanien- 
berg in Hainfeld (Pfalz) for kindly providing us with all the data for sugar concentrations and harvest quantities since 1994. We are grateful to PD Dr. Ewald Sieverding (Germany) and Dr. Danny Coyne (United Kingdom) for their valuable comments, suggestions and English language advice.

\section{Author Contributions}

BK and FO conceived and designed the study. BK collected all the data. FO analyzed the data. BK and FO wrote the manuscript.

\section{References}

[1] Jones, G.V., White, M.A., Cooper, O.R. and Storchmann, K. (2005) Climate Change and Global Wine Quality. Climate Change, 73, 319-343.

https://doi.org/10.1007/s10584-005-4704-2

[2] Schultz, H.R. (2010) Climate Change and Viticulture: Research Needs for Facing the Future. Journal of Wine Research, 21, 113-116. https://doi.org/10.1080/09571264.2010.530093

[3] Hannah, L., Roehrdanz, P.R., Ikegami, M., Shepard, A.V., Shaw, M.R., Tabor, G., Zhi, L., Marquet, P.A. and Hijmans, R.J. (2013) Climate Change, Wine, and Conservation. Proceedings of the National Academy of Sciences, 110, 6907-6912. https://doi.org/10.1073/pnas.1210127110

[4] Mozell, M.R. and Thach, L. (2014) The Impact of Climate Change on the Global Wine Industry: Challenges \& Solutions. Wine Economics and Policy, 3, 81-89. https://doi.org/10.1016/j.wep.2014.08.001

[5] Mosedale, J.R., Abernethy, K.E., Smart, R.E., Wilson, R.J. and Maclean, I. (2016) Climate Change Impacts and Adaptive Strategies: Lessons from the Grapevine. Global Change Biology, 22, 3814-3828. https://doi.org/10.1111/gcb.13406

[6] Lichine, A., Casamayor, P., Gryn, J. and Lebey, C. (1998) Encyclopedia of the Wines and the Alcohols of All Countries. In: Laffont, R., Ed., Collection Bouquins, 870. (In French)

[7] Dettweiler, E., Jung, A., Zyprian, E. and Töpfer, R. (2000) Grapevine Cultivar Müller-Thurgau and Its True to Type Descent. Vitis, 39, 63-66.

[8] Riebel, M., Fronk, P. Tenzer, S. and Decker, H. (2017) Proteomic Profiling of German Dornfelder Grape Berries Using Data-Independent Acquisition. Plant Physiology and Biochemistry,118, 64-70. https://doi.org/10.1016/j.plaphy.2017.06.003

[9] Galet, P. and Grisard, M. (2015) Dictionary Encyclopedique of the Grapevine Varieties and Their Synonyms. Éditions Libre et solidaire-Medial, 1200. (In French)

[10] Bock, A., Sparks, T.H., Estrella, N. and Menzel, A. (2013) Climate-Induced Changes in Grapevine Yield and Must Sugar Content in Franconia, Germany, between 1805 and 2010. PLOS One, 8, e69015. https://doi.org/10.1371/journal.pone.0069015

[11] van Leeuwen, C. and Seguin, G. (2006) The Concept of Terroir in Viticulture. Journal of Wine Research, 17, 1-10. https://doi.org/10.1080/09571260600633135

[12] Huglin, P. (1978) Nouveau mode d'évaluation des possibilités héliothermiques d'un milieu viticole. Comptes Rendus de l'Académie d'Agriculture de France, 64, 1117-1126.

[13] Duchêne, E. and Schneider, C. (2005) Grapevine and Climatic Changes: A Glance at the Situation in Alsace. Agronomy for Sustainable Development, 25, 93-99. 
https://doi.org/10.1051/agro:2004057

[14] Petgen, M. (2007) Chances and Limits of Ripening Control: How Flexible Is Grapevine? Das Deutsche Weinmagazin, 7/8, 42-47. (In German)

[15] Bock, A., Sparks, T.H., Estrella, N. and Menzel, A. (2011) Changes in the Phenology and Composition of Wine from Franconia, Germany. Climate Research, 50, 69-81. https://doi.org/10.3354/cr01048

[16] Jüstrich, H. (2013) Climate Change: Fact or Fiction. Schweizer Zeitschrift Obst- und Weinbau, 16/13, 3-7. (In German)

[17] de Cortázar-Atauri, I.G., Duchêne, E., Destrac-Irvine, A., Barbeau, G., de Rességuier, L., Lacombe, T., Parker, A.K., Saurin, N. and van Leeuwen, C. (2017) Grapevine Phenology in France: From Past Observations to Future Evolutions in the Context of Climate Change. OENO One, 51, 115-126. https://doi.org/10.20870/oeno-one.2016.0.0.1622

[18] Schultz, H.R. and Jones, J.V. (2010) Climatic Induced Historic and Future Changes in Viticulture. Journal of Wine Research, 21, 137-145. https://doi.org/10.1080/09571264.2010.530098

[19] IPCC (2013) Climate Change 2013: The Physical Science Basis. Contribution of Working Group I to the Fifth Assessment Report of the Intergovernmental Panel on Climate Change. Cambridge University Press, Cambridge, 1535 p.

[20] Duchêne, E., Huard, F. and Pieri, P. (2014) Grapevine and Climate Change: What Adaptions of Plant Material and Training Systems Should Be Anticipate. Journal International de Sciences de la Vigne et du Vin, 48, 61-69.

[21] Duchêne, E., Huard, F., Dumas, V., Schneider, C. and Merdinoglu, D. (2010) The Challenge of Adapting Grapevine Varieties to Climate Change. Climate Research, 41, 193-204. https://doi.org/10.3354/cr00850

[22] Duchêne, E. (2016) How Can Grapevine Genetics Contribute to the Adaptation to Climate Change? OENO One, 50, 113-124. https://doi.org/10.20870/oeno-one.2016.50.3.98

[23] Eibach, R. and Töpfer, R. (2015) Traditional Grapevine Breeding Techniques. In: Reynolds, A., Ed., Grapevine Breeding Programs for the Wine Industry. Woodhead Publishing, Cambridge, 3-21. https://doi.org/10.1016/B978-1-78242-075-0.00001-6

[24] De Oruña, R.M. (2010) Climate Change Associated Effects on Grape and Wine Quality and Production. Food Research International, 43, 1844-1855. https://doi.org/10.1016/j.foodres.2010.05.001

[25] Mass, U. and Schwab, A. (2011) Climate Change and Choice of Grapevine Varieties -the Huglin-Index and the Heat Claim of Grapevine. Das deutsche Weinbaumagazin, 5, 29-31. (In German)

[26] Holzkämper, A. and Fuhrer, J. (2013) Trends of Temperature and Viticulture in Switzerland. Schweizer Zeitschrift für Obst- und Weinbau, 16/13, 3-7. (In German)

[27] Linder, C., Scharer, S., Kehrli, P., Jermini, M., Blaser, S. and Bünder, M. (2017) The "Flavescence dorée" ("Golden Yellowing") in the North of the Alps. Schweizer Zeitschrift für Obst- und Weinbau, 153, 4-11. (In German)

[28] Schaerer, S., Linder, C. and Jeanrenaud, M. (2017) The "Flavescence dorée" ("Golden Yellowing") in the North of the Alps, a Balance 2016. Revue suisse Viticulture, Arboriculture, Horticulture, 49, 59-60. (In French)

[29] Launay, M., Caubel, J., Bourgeois, G., Huard, F., Cortazar-Atauri, I.G., Bancal, M.O. and Brisson, N. (2014) Climatic Indicators for Crop Infection Risk: Application to 
Climate Change Impacts on Five Major Foliar Fungal Diseases in Northern France. Agriculture, Ecosystems and Environments, 197, 147-158. https://doi.org/10.1016/j.agee.2014.07.020

[30] Angelotti, F., Hamada, E., Magalhães, E.F., Ghini, R., Garrido, L.D.R. and Júnior, M.J.P. (2017) Climate Change and the Occurrence of Downy Mildew in Brazilian Grapevines. Pesquisa Agropecuária Brasileira, 52, 426-434. https://doi.org/10.1590/s0100-204x2017000600006

[31] Moriondo, M., Jones, G.V., Bois, B., Dibari, C., Ferrise, R., Trombi, G. and Bindi, M. (2013) Projected Shifts of Wine Regions in Response to Climate Change. Climate Change, 119, 825-839. https://doi.org/10.1007/s10584-013-0739-y

[32] van Leeuwen, C., Schultz, H.R., de Cortazar-Atauri, I.G., Duchêne, E., Ollat, N., Pieri, P., Bois, B., Goutouly, J.P., Quénol, H., Touzard, J.-M., Malheiro, A.C., Bavaresco, L. and Delrot, S. (2013) Why Climate Change Will Not Dramatically Decrease Viticultural Suitability in Main Wine-Producing Areas by 2050. Proceedings of the National Academy of Sciences, 110, 3051-3052.

https://doi.org/10.1073/pnas.1307927110

[33] Lazoglou, G., Anagnostopoulou, C. and Koundouras, S. (2017) Climate Change Projections for Greek Viticulture as Simulated by a Regional Climate Model. In: Theoretical and Applied Climatology, Springer, Vienna, 1-17. https://doi.org/10.1007/s00704-017-2198-2

[34] Ponti, L., Guitierrez, A.P., Ruti, P.M. and Dell'Aquila, A. (2014) Fine-Scale Ecological and Economic Assessment of Climate Change on Olive in the Mediterranean Basin Reveals Winners and Losers. Proceedings of the National Academy of Sciences of the United States of America, 111, 5598-5603. https://doi.org/10.1073/pnas.1314437111

[35] Kizildeniz, T., Mekni, I., Santesteban, H., Pascual, I., Morales, F. and Irigoyen, J.J. (2015) Effects of Climate Change Including Elevated $\mathrm{CO}_{2}$ Concentration, Temperature and Water Deficit on Growth, Water Status, and Yield Quality of Grapevine (Vitis vinifera L.) Cultivars. Agricultural Water Management, 159, 155-164. https://doi.org/10.1016/j.agwat.2015.06.015

[36] Leibar, U., Aizpurna, A., Unamunzaga, O., Pascual, I. and Morales, F. (2015) How Will Climate Change Influence Grapevine cv. Tempranillo Photosynthesis under Different Soil Textures? Photosynthesis Research, 124, 199-215. https://doi.org/10.1007/s11120-015-0120-2

[37] van Leeuwen, C., Trégoat, O., Choné, X., Bois, B., Pernet, D. and Gaudillère, P. (2009) Vine Water Status Is a Key Factor in Grape Ripening and Vintage Quality for Red Bordeaux Wine. How Can It Be Assessed for Vineyard Management Purposes? OENO One, 43, 121-134.

https://doi.org/10.20870/oeno-one.2009.43.3.798

[38] Webb, L.B., Whetton, P.H. and Barlow, E.W.R. (2008) Climate Change and Winegrape Quality in Australia. Climate Research, 36, 99-111. https://doi.org/10.3354/cr00740

[39] Adams, D.O. (2006) Phenolics and Ripening in Grape Berries. American Journal of Enology and Viticulture, 57, 249-256. 